\title{
MANAJEMEN PELAYANAN PUBLIK DALAM PERSPEKTIF ISLAM (Studi di Rumah Sakit Ibnu Sina Kota Pekanbaru)
}

\author{
Muhammad Rachmadi dan Muslim \\ Fakultas Ekonomi dan Ilmu Sosial UIN Sultan Syarif Kasim Riau \\ J1. HR Soebrantas 155 Km 15 Simpang Baru Panam Pekanbaru 28293 \\ e-mail: muslimrahman83@yahoo.co.id
}

\begin{abstract}
This study aimed at examining the relationship between Islamic values and public services. To achieve the purpose it employed survey research design. The patients in Ibnu Sina Islamic hospital were assigned as respondents and questionnaire was used to assess their perceptions toward the values and the quality services provided by the hospital. The findings showed that 1) the implementation of the Islamic values provided by the hospital was in general was 'good', 2) the quality of public services in general was also 'good', and 3) the correlation between the implementation of Islamic values and the quality of public services was 'positive' ( 0.458 on Pearson Product Moment index). It can be concluded that the more Islamic values were implemented, the quality of public services tended to be more realized. Theoretically, the finding were expected to yield evidence that there was positive correlation between organizational culture, especially religious values, and organizational performance, especially quality of public services. Practically, the findings encouraged the hospital managers to keep improving their implementation of Islamic values since the of quality of public services tended to increase as well.
\end{abstract}

Kata kunci: nilai-nilai Islam, pelayanan publik, rumah sakit Islam Ibnu Sina

\section{PENDAHULUAN}

D

isahkannya Undang Undang No. 25 tahun 2009 tentang Pelayanan Publik menjadi dasar hukum yang lex specialis bagi penyelenggaraan pelayan publik di Indonesia. Dalam Undang-undang ini menjelaskan secara kongkret makna pelayanan, di mana pelayanan publik merupakan kegiatan atau rangkaian kegiatan dalam rangka pemenuhan kebutuhan pelayanan sesuai dengan peraturan perundang-undangan bagi setiap warga Negara dan penduduk atas barang, jasa dan/atau pelayanan administratif yang disediakan oleh penyelenggara pelayanan masyarakat. Dalam Undang-undang ini mewajibkan kepada para penyelenggara pelayanan untuk menyusun dan menetapkan standar pelayanan. Dalam pasal 21 dijelaskan bahwa komponen standar pelayanan sekurang-kurangnya meliputi: (1) dasar hukum; (2) persyaratan; (3) sistem, mekanisme, dan prosedur; (4) jangka waktu penyelesaian; (5) biaya/tarif; (6) produk pelayanan; 
(7) sarana, prasarana dan/atau fasilitas; (8) kompetensi pelaksana; (9) pengawasan internal; (10) penanganan pengaduan, saran, dan masukan; (11) jumlah pelaksana; (12) jaminan pelayanan yang memberikan kepastian pelayanan dilaksanakan sesuai dengan standar pelayanan; (13) jaminan keamanan dan keselamatan pelayanan dalam bentuk komitmen untuk memberikan rasa aman, bebas dari bahaya, dan risiko keragu-raguan; (14) evaluasi kinerja pelaksana.

Pelayanan yang menjadi konsen pemerintah Indonesia ialah bagaimana menyediakan pelayanan kesehatan, di mana masih banyaknya masyarakat membutuhkan pelayanan ini. Berbagai faktor menjadikan pelayanan kesehatan menjadi penting salah satunya melemahnya pertumbuhan ekonomi Indonesia khususnya dari tahun 2012 - 2014, yang berakibat meningkatnya orang miskin di Indonesia seperti berikut ini :

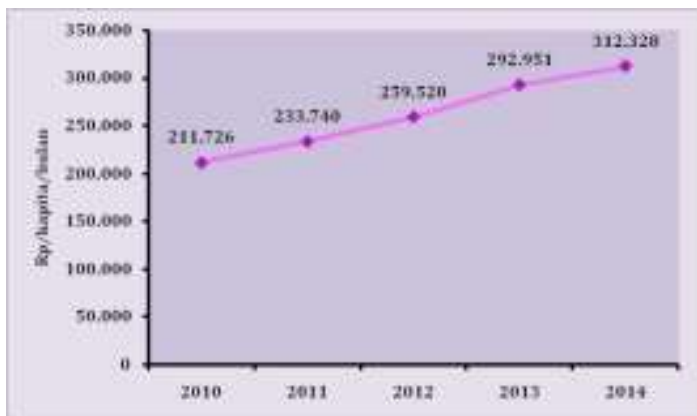

Sumber: Badan Pusat Statistik, 2015

Dalam pelaksanaan pelayanan kesehatan ini dibutuhkan kesadaran semua pihak baik petugas kesehatan mapun masyarakat. Kesadaran ini tentu didasari oleh pemahaman yang universal dan inheren dalam diri seseorang, yaitu kepercayaan dan budaya yang menjadi indentitas. Islam agama yang universal dan dipahami oleh pemeluknya sebagai ajaran yang menjamin keselamatan, sehingga dapat menumbuhkan dan memupuk motivasi untuk berbuat yang terbaik bagi diri sendiri dan orang lain.

Dalam tulisan ini penulis angkat dari suatu peneliti yang membahas tentang penerapan nilainilai Islam dalam pelayanan masyarakat. Dalam Islam menuangkan suatu sistem ajaran yang berupa akidah, syariah, dan akhlak. Nilai-nilai Islam ini sendiri adalah bagaimana adanya persamaan jenjang (derajat) antar manusia, semangat persaudaraan, tanggung jawab, orientasi pada kebaikan, keadilan, kejujuran, amanah, pengabdian/ ibadah, keikhlasan, kebersihan, mendahulukan melaksanakan kewajiban, memberikan pertolongan, berakhlak mulia, prinsip toleransi, musyawarah, dan kedamaian.

Rumusan masalah penelitian ini adalah:

1. Bagaimanakah penerapan nilainilai Islam dalam pelayanan publik di Rumah Sakit Islam Ibnu Sina Kota Pekanbaru?

2. Bagaimanakah kualitas pelayanan publik di Rumah Sakit Islam Ibnu Sina Kota Pekanbaru?

Bagaimanakah hubungan penerapan nilai-nilai Islam dengan kualitas pelayanan publik di Rumah Sakit Islam Ibnu Sina Kota Pekanbaru? 


\section{HIPOTESIS}

1. Penerapan nilai-nilai keagamaan di Rumah Sakit Islam Ibnu Sina Kota Pekanbaru telah mencapai persentase yang tinggi.

2. Kualitas pelayanan masyarakat di Rumah Sakit Islam Ibnu Sina Kota Pekanbaru telah mencapai persentase yang tinggi.

3. Ada hubungan yang positif dan signifikan antara penerapan nilainilai keagamaan dengan kualitas pelayanan masyarakat di Rumah Sakit Islam Ibnu Sina Kota Pekanbaru.

\section{METODE PENELITIAN}

\section{Lokasi dan Waktu Penelitian}

Penelitian ini dilaksanakan oleh peneliti adalah di Rumah Sakit Islam Ibnu Sina Kota Pekanbaru yang beralamat di Jalan Melati No. 60, Pekanbaru pada tahun 2015.

\section{Sumber Data}

Sumber datanya adalah para informan dan responden penelitian. Cara memperoleh sumber data informan penelitian ini dilakukan melalui teknik key-person dari para pejabat dan staf rumah sakit itu. Karena karakteristik populasi relatif homogen, maka cara memperoleh sumber data responden penelitian ini dilakukan melalui teknik simple random-sampling dari para pasien pada rumah sakit itu.

\section{Teknik Pengumpulan Data}

Teknik pengumpulan data sebagai berikut :

1. Angket (Kuisioner)
2. Wawancara Mendalam (in-depth interview)

3. Dokumentasi

\section{Populasi dan Sampel}

\section{Populasi}

Populasi dalam penelitian ini adalah pasien (keluarga pasien yang mewakili) yang menerima pelayanan masyarakat di Rumah Sakit Islam Ibnu Sina Kota Pekanbaru, yang didasari dari pengguna jasa sampai pada bulan Oktober Tahun 2015, yaitu:

Tabel 1

Jumlah Pasien Rawat Inap Tahun 2010-2014

\begin{tabular}{|c|c|c|}
\hline Tahun & $\begin{array}{c}\text { Jumlah Pasien } \\
\text { Rawat Inap } \\
\text { (orang) }\end{array}$ & Persen \\
\hline 2010 & 9.378 & $67,7 \%$ \\
\hline 2011 & 10.855 & $73,0 \%$ \\
\hline 2012 & 10.576 & $70,4 \%$ \\
\hline 2013 & 9.228 & $63,1 \%$ \\
\hline 2014 & 10.368 & $69,9 \%$ \\
\hline
\end{tabular}

Sumber: RS. Ibnu Sina Kota Pekanbaru 2015

Maka populasi tersebut menjadikan dasar untuk mendapatkan sampel penelitian.

\section{Sampel}

Sampel dalam penelitian ini diambil dari jumlah populasi atau pengguna jasa di Rumah Sakit Islam Ibnu Sina Kota Pekanbaru sampai pada tahun 2014 sebanyak 10.368 orang. Adapun cara untuk menentukan jumlah sampel menggunakan rumus Slovin (Umar, 2003: 146). Dengan rumus:

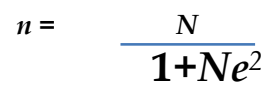


Dimana :

$\mathrm{n}=\quad$ Ukuran Sampel

$\mathrm{N}=$ Ukuran Populasi

$e=$ Persen kelonggaran ketidak telitian Kesalahan pengambilan sampel yang dapat ditolerir.

$$
\begin{aligned}
& n=\frac{N}{1+N e^{2}} \\
& n=\frac{10.368}{1+10.368} \times 10 \%^{2} \\
& n=\frac{10.368}{1+103,68} \\
& n=\frac{10.368}{104,68} \\
& n=99,0447=99 \text { Orang }
\end{aligned}
$$

Jadi, jumlah sampel yang diperlukan sebesar 99 orang pengguna jasa di Rumah Sakit Islam Ibnu Sina Kota Pekanbaru.

Sedangkan pengambilan sampel yang digunakan adalah metode purposive sampling, di mana teknik penentuan sampel dengan pertimbangan tertentu, yaitu orang tersebut benarbenar pengguna dalam pelayanan masyarakat bidang kesehatan (orang yang dipilih sesuai dengan kriteria). (Sugiono, 2006: 78).

\section{Teknik Analisis Data}

Untuk menganalisis data yang diperoleh penulis menggunakan metode deskriptif dan kuantitatif.

Metode deskriptif dimaksudkan untuk menjelaskan serta menganalisa Kualitas pelayanan masyarakat di Rumah Sakit Islam Ibnu Sina Kota Pekanbaru berdasarkan data-data yang diperoleh dan menghubungkan teori-teori yang relevan dengan permasalahan yang diteliti.

Metode kuantitatif, yaitu dengan metode linear berganda (Multiple Linear Regression) untuk mengukur Kualitas pelayanan masyarakat di Rumah Sakit Islam Ibnu Sina Kota Pekanbaru.

Untuk pengujiannya dinyatakan dengan rumus regresi sederhana (Haryono, 1995: 204):

$\mathbf{Y}=\mathbf{a}+\mathbf{b X}+\mathbf{e}$

Dimana,

$\mathrm{Y}=$ Yaitu kepuasan pelayanan masyarakat (Keterampilan Fisik

(Tangibles), Akses (Access),

Reliabilitas (Reliability),

Kredibilitas (Credibility),

Keamanan (Ansurence),

Kompetensi (Competence),

Komunikasi (Communication),

Kesopanan (Courtessy),

Responsivitas (Responsivennes).

Pengertian (Anderstending)

$\mathrm{X}=$ Yaitu Penerapan nilai-nilai KeIslaman

Selanjutnya untuk menguji hipotesis dan pengaruh variabelvariabel bebas (independent) secara keseluruhan terhadap variabel terikat (dependent) dilakukan dengan uji $\mathrm{F}$ dengan membandingkan Fhitung dengan F-tabel pada tingkat signifikan $a=0,05$. Dimana jika Fhitung > F-tabel maka variabel bebas dapat menerangkan variabel tergantung, berarti ada pengaruh antara variabel terhadap variabel tergantungnya.

Untuk membuktikan hipotesis secara parsial digunakan uji T, yaitu dengan membandingkan thitung dengan t-tabel pada tingkat signifikan $a=0,05$. Jika $t$-hitung $>\mathrm{t}$ - 
tabel maka variabel tidak bebasnya dan ini berarti ada pengaruh antara dua variabel.

Kemudian untuk mendapatkan hasil data dari variabel tersebut penulis mentransformasikan data kualitatif dan kuesioner yang disebarkan kepada pengguna layanan rumah sakit menjadi data kuantitatif dengan memberikan skor atau bobot nilai pada kuesioner. Untuk menentukan nilai jawaban tiap pertanyaan digunakan skala likert dengan lima alternatif jawaban (J. Supranto, 1997: 86), yaitu :
A. Menyatakan
Sangat
Benar

kenyataannya, bobot nilai $=5$

B. Menyatakan Benar kenyataannya, boot nilai $=4$

C. Menyatakan Agak Benar kenyataannya, bobot nilai $=3$

D. Menyatakan Tidak Benar kenyataannya, bobot nilai $=2$

E. Menyatakan Sangat Tidak Benar kenyataannya, bobot nilai $=1$

Dari hasil skor ini dilakukan analisa matematis dengan menggunakan komputer untuk mempermudah melakukan analisa data yaitu dengan menggunakan program SPSS 16.

\section{Analisis Data}

Teknik analisis datanya dilakukan dengan menggunakan teknik statistik. Teknik statistik yang digunakan untuk analisis data dan menguji hipotesis, untuk hipotesis asosiatif, dengan data berbentuk interval (instrumennya menggunakan skala Likert), maka pengujian hipotesis menggunakan teknik statistik Korelasi Product Moment.

\section{TINJAUAN PUSTAKA}

\section{Konsep Pelayanan}

Pelayanan pada dasarnya dapat didefinisikan sebagai aktifitas seseorang, sekelompok, dan atau organisasi baik langsung maupun tidak langsung untuk memenuhi kebutuhan. Monir mengatakan bahwa pelayanan adalah proses pemenuhan kebutuhan-kebutuhan melalui aktifitas orang lain secara langsung (Pasolong, 2011: 128). Sedangkan Menteri Pendayagunaan Aparatur Negara

(1993), mengemukakan bahwa pelayanan adalah segala bentuk kegiatan pelayanan dalam bentuk barang atau jasa dalam rangka upaya pemenuhan kebutuhan masyarakat.

Pelayanan publik menurut Sinembela adalah sebagai setiap kegiatan yang dilakukan oleh pemerintah terhadap sejumlah manusia yang memiliki setiap kegiatan yang menguntungkan dalam suatu kumpulan atau kesatuan, dan menawarkan kepuasan meskipun hasilnya tidak terikat pada suatu produk secara fisik (Pasolong, 2011: 128)

Definisi pelayanan publik menurut Kepmen PAN Nomor 25 tahun 2004 adalah segala kegiatan pelayanan yang dilaksanakan oleh penyelenggara pelayanan publik sebagai upaya pemenuhan kebutuhan penerima layanan, maupun dalam rangka pelaksanaan ketentuan peraturan perundang- 
undangan. Sedangkan Kepmen PAN Nomor $58 \quad$ Tahun 2002 mengelompokkan tiga jenis pelayanan dari instansi pemerintah serta BUMN atau BUMD. Pengelompokkan jenis pelayanan tersebut didasarkan pada ciri-ciri dan sifat kegiatan serta produk pelayanan yang dihasilkan, yaitu

1. Pelayanan administratif

2. Pelayanan barang

3. Pelayanan jasa

\section{Kualitas Pelayanan}

Kualitas pada dasarnya merupakan kata yang menyandang arti relatif karena bersifat abstrak, kualitas dapat digunakan untuk menilai atau menentukan tingkat penyesuaian suatu hal terhadap persyaratan atau spesifikasinya.

Kualitas menurut Fandy Tjiptono adalah 1) kesesuaian dengan persyaratan atau tuntutan, 2) kecocokan pemakaian, 3) perbaikan atau penyempurnaan keberlanjutan, 4) bebas dari kerusakan, 5) pemenuhan kebutuhan pelanggan semenjak awal dan setiap saat, 6) melakukan segala sesuatu secara benar semenjak awal, 7) sesuatu yang bisa membahagiakan pelanggan (Pasolong, 2011: 132).

Kasmir mengatakan bahwa pelayanan yang baik adalah kemampuan seseorang dalam memberikan pelayanan yang dapat memberikan kepuasan kepada pelanggan dengan standard yang ditentukan (Pasolong, 2011: 133). Menurut Zethami \& Haywood Farmer mengatakan ada tiga karakteristik utama tentang pelayanan, yaitu (Pasolong, 2011: 133-134):

1. Intangibility berarti bahwa pelayanan pada dasarnya bersifat performance dan hasil pengalaman dan bukannya objek. Kebanyakan pelayanan tidak dapat dihitung, diukur, diraba atau dites sebelum disampaikan untuk menjamin kualitas. Berbeda dengan barang yang dihasilkan oleh suatu pabrik yang dapat dites kualitasnya sebelum disampaikan pada pelanggan.

2. Heterogeinity berarti pemakai jasa atau klien atau pelanggan memiliki kebutuhan yang sangat heterogen. Pelanggan dengan pelayanan yang sama mungkin mempunyai prioritas berbeda. Demikian pula performance sering bervariasi dari suatu prosedur ke prosedur lainnya bahkan dari waktu ke waktu.

3. Inseparability berarti bahwa produki dan konsumsi suatu pelayanan tidak terpisahkan. Konsekuensinya di dalam industri pelayanan kualitas tidak direkayasa ke dalam produksi di sektor pabrik dan kemudian disampaikan kepada pelanggan. Kualitas terjadi selama interaksi antara klien dan penyedia jasa.

Untuk mengetahui kualitas pelayanan yang dirasakan secara nyata oleh konsumen, ada indikator ukuran kepuasan konsumen yang terletak pada lima dimensi kualitas pelayanan menurut apa yang dikatakan konsumen. Kelima dimensi servqual tersebut (Zeithhami-Parasurman-Berry, 1990: t.h.), yaitu: 
1. Tangibles: kualitas pelayanan berupa sarana fisik perkantoran, komputerisasi administrasi, ruang tunggu, tempat informasi.

2. Reability: kemampuan dan keandalan untuk menyediakan pelayanan yang terpercaya.

3. Responsivess: kesanggupan untuk membantu dan menyediakan pelayanan secara cepat dan tepat, serta tanggap terhadap keinginan konsumen.

4. Assurance: kemampuan dan keramahan serta sopan santun pegawai dalam meyakinkan kepercayaan konsumen.

5. Emphaty: sikap tegas tetapi penuh perhatian dari pegawai terhadap konsumen.

\section{Konsep Islam dalam Pelayanan Masyarakat.}

Islam sebagai suatu agama merupakan sistem akidah, syariah, dan akhlak. Nilai-nilai Islam antara lain adalah persamaan derajat antar manusia, semangat persaudaraan, tanggung jawab, orientasi pada kebaikan, keadilan, kejujuran, amanah, pengabdian/ ibadah, keikhlasan, kebersihan, mendahulukan melaksanakan kewajiban, memberikan pertolongan, berakhlak mulia, prinsip toleransi, musyawarah, dan kedamaian.

Jauh-jauh sebelumnya, Islam telah mengajarkan kepada seluruh umat manusia (bukan saja untuk umat Islam) untuk senantiasa memberikan pelayanan yang berkualitas sebagaimana firman Allah SWT:

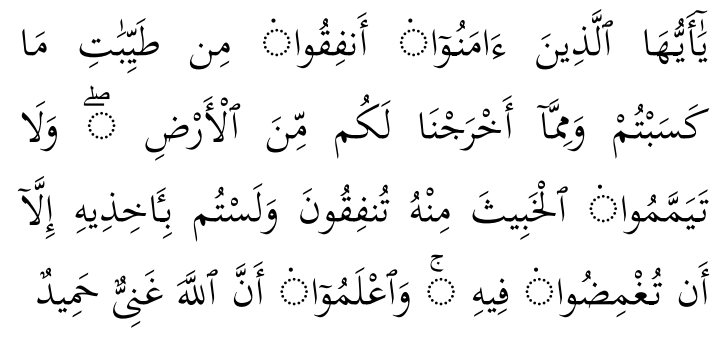

Hai orang-orang yang beriman nafkanlah (dijalan Allah) sebagian dari hasil usahamu yang baik-baik dan sebagian dari apa yang kami keluarkan dari bumi untuk kamu. Dan janganlah kamu memilih yang buruk-buruk lalu menafkahkan daripadanya, padahal kamu sendiri tidak mau mengambilnya melainkan dengan memincingkan mata terhadapnya. Dan ketahuilah, bahwa Allah Maha Kaya lagi Maha Terpuji. (Q.S. al-Baqarah [2]: 267.)

Apabila kita tarik ke ranah pelayanan, maka ayat tersebut dapat bermakna bahwa para petugas pelayan, hendaknya melayani dan memperlakukan seseorang dengan baik sebagaimana ia memperlakukan dirinya sendiri.

1. Pelayanan Kesehatan yang Islami di Rumah Sakit Islam

Tidak mudah untuk memberikan definisi pelayanan kesehatan yang Islami di rumah sakit Islam. Pengertian sederhana tentang pelayanan kesehatan yang Islami adalah segala bentuk kegiatan asuhan medik dan asuhan keperawatan yang dibingkai dengan kaidah-kaidah Islam.

Melaksanakan pelayanan kesehatan profesional yang Islami dengan berpedoman kepada kaidah-kaidah Islam, medik dan keperawatan yang mencakup: (1) 
menerapkan konsep, teori, dan prinsip dalam keilmuan yang terkait dengan asuhan medik dan asuhan keperawatan dengan mengutamakan pedoman pada alquran dan hadis, (2) melaksanakan asuhan medik dan asuhan keperawatan dengan menggunakan pendekatan Islami melalui kegiatan-kegiatan pengkajian yang berdasarkan bukti (evidence-based healthcare), (3) mempertanggungjawabkan atas segala tindakan dan perbuatan yang berdasarkan bukti (evidencebased healthcare), (4) berlaku jujur, ikhlas dalam memberikan pertolongan kepada pasien baik secara individu, keluarga, kelompok maupun masyarakat dan semata-mata mengharapkan ridho Allah, (5) bekerjasama dengan tenaga kesehatan lainnya untuk meningkatkan mutu pelayanan kesehatan dan menyelesaikan masalah pelayanan kesehatan yang berorientasi pada asuhan medik dan asuhan keperawatan yang berdasarkan bukti (evidence-based healthcare).

2. SDM yang terlibat dalam pelayanan kesehatan yang Islami Sebagai hamba Allah para dokter dan perawat yang bekerja di rumah sakit Islam adalah seorang muslim yang mempunyai tujuan hidup hasanah fid-dunya dan hasanah fil-akhirah.

Dalam

melaksanakan pelayanan kesehatan yang Islami di rumah sakit, para dokter dan perawat muslim haruslah mencerminkan pada pengetahuan, sikap, dan ketrampilan profesional.

3. Sifat-sifat yang harus dimiliki oleh dokter dan perawat muslim

Islam telah menetapkan beberapa sifat-sifat terpuji bagi manusia. Secara khusus, dokter dan perawat Muslim yang melaksanakan pelayanan kesehatan harus mempunyai sifatsifat sebagai berikut: (1) tulus ikhlas karena Allah (al-Bayyinah [98]: 5), (2) penyantun (al-A'raf [7], 56; al-Baqarah [2]: 263); (3) ramah ( Ali Imron [3]: 159,); (4) sabar (asy-Syura [26]: 43), (5) tenang (hadis riwayat Ibnu Sa'ad), (6) tegas (Hadis, riwayat Ahmad dan Bukhari), (7) patuh pada peraturan (Riwayat Bukhari, Muslim, dan Abu Daud), (8) bersih (at-Taubah [9]: 108, AlMuddattsir [74]: 4; Hadis, riwayat Abu Daud), (9) penyimpan rahasia (an-Nisa [4]: 148, an-Nur [24]: 19, Hadis, riwayat Ibnu Majjah, Abu Daud, Muslim, Abu Hurairah), (10) dapat dipercaya (al-Mukminun [23]: 1-11, al-Anfal [8]: 27, an-Nisa [4] 58, Hadis, riwayat Ahmad), bertanggungjawab (al-Isra' [17]: 36, Hadis, riwayat Ibnu Hibban, Anas bin Malik, dan Ahmad).

4. Organisasi manajemen rumah sakit yang Islami

Secara umum organisasi manajemen rumah sakit yang Islami mencakup kegiatan sebagai berikut: (1) menerapkan teori manajemen dan kepemimpinan berdasarkan kaidah-kaidah Islam, (2) melakukan fungsi manajemen 
dengan berpedoman kepada syariah Islam serta menerapkan akhlakul karimah, (3) pimpinan rumah sakit bertindak sebagai ulama dan umara untuk meningkatkan motivasi dan kinerja pelayanan kesehatan, (4) pimpinan rumah sakit menjadi contoh yang baik (uswatun hasanah) dalam berperan sebagai tenaga medis dan perawat profesional Islam.

5. Lingkungan yang Islami di rumah sakit Islam

Lingkungan yang Islami di rumah sakit Islam tentu akan terlihat adanya suasana keagamaan (ada mesjid, shalat jama'ah, hiasan-hiasan dinding yang ada kaitannya kesehatan dan Islam), kenyamanan, kebersihan, ketenangan, kesejukan, ketertiban, disiplin, mudah mendapatkan informasi, cepat mendapatkan pelayanan dan keramah-tamahan seluruh karyawan yang bekerja di rumah sakit.

\section{PEMBAHASAN HASIL PENELITIAN}

Penerapan Nilai-Nilai Islam dalam pelayanan di Rumah Sakit Ibnu Sina Kota Pekanbaru

Dalam pelaksanaan ataupun penerapan terhadap nilai-nilai Islam yang dilakukan pada di Rumah Sakit Ibnu Sina Pekanbaru dapat peneliti jelaskan sebagai berikut:

Tabel 2

Nilai Indeks Perunsur Penerapan Nilai-nilai Islami

\begin{tabular}{|c|c|l|c|c|}
\hline No & Pertanyaan ke & \multicolumn{1}{|c|}{ Aspek } & $\begin{array}{c}\text { Nilai } \\
\text { (Persen) }\end{array}$ & $\begin{array}{c}\text { Nilai } \\
\text { Indek }\end{array}$ \\
\hline 1 & 19 & Kumandang adzan & $95 \%$ & 4,75 \\
\hline 2 & 2 & $\begin{array}{l}\text { Mengucapkan } \\
\text { "bismillahirrohmanirrahim" }\end{array}$ & $94 \%$ & 4,70 \\
\hline 3 & 1 & Mengucapkan “assalamu'alaikum” & $92 \%$ & 4,60 \\
\hline 4 & 7 & $\begin{array}{l}\text { Bagian bina rohani kunjungan ke } \\
\text { ruangan }\end{array}$ & $91 \%$ & 4,55 \\
\hline 5 & 12 & Penampilan petugas selalu Islami & $90 \%$ & 4,50 \\
\hline 6 & 18 & Tersedianya mushola/mesjid & $90 \%$ & 4,50 \\
\hline 7 & 3 & Pengucapan “alhamdulillah" & $88 \%$ & 4,40 \\
\hline 8 & 5 & $\begin{array}{l}\text { Anjuran berzikir ketika terasa } \\
\text { kesakitan }\end{array}$ & $88 \%$ & 4,40 \\
\hline 9 & 8 & $\begin{array}{l}\text { Petugas Bina Rohani berikan } \\
\text { tuntunan doa }\end{array}$ & $88 \%$ & 4,40 \\
\hline 10 & 9 & $\begin{array}{l}\text { Petugas menjalankan shalat } 5 \\
\text { waktu }\end{array}$ & $88 \%$ & 4,40 \\
\hline 11 & 11 & Membimbing doa ketika mau & $87 \%$ & 4,35 \\
\hline
\end{tabular}




\begin{tabular}{|c|c|l|c|c|}
\hline & & operasi & & \\
\hline 12 & 4 & $\begin{array}{l}\text { Pengucapan salam masuk ruang } \\
\text { perawatan }\end{array}$ & $86 \%$ & 4,30 \\
\hline 13 & 13 & Petugas ramah dan santun & $86 \%$ & 4,30 \\
\hline 14 & 14 & $\begin{array}{l}\text { Tulisan hadis/ ayat alquran di } \\
\text { dinding }\end{array}$ & $86 \%$ & 4,30 \\
\hline 15 & 6 & Petugas membimbing doa/berzikir & $85 \%$ & 4,25 \\
\hline 16 & 10 & $\begin{array}{l}\text { Petugas mau membimbing shalat } 5 \\
\text { waktu }\end{array}$ & $84 \%$ & 4,20 \\
\hline 17 & 20 & $\begin{array}{l}\text { Lantunan ayat alquran / lagu } \\
\text { Islami }\end{array}$ & $81 \%$ & 4,05 \\
\hline 18 & 15 & Buku tuntunan rohani utk pasien & $76 \%$ & 3,80 \\
\hline 19 & 16 & $\begin{array}{l}\text { Tersedia alquran/alat shalat di } \\
\text { ruangan }\end{array}$ & $69 \%$ & 3,45 \\
\hline 20 & 17 & Media untuk tayamum & $61 \%$ & 3.05 \\
\hline & & \multicolumn{1}{|c|}{ Rata-rata Indek } & $81 \%$ & 4,26 \\
\hline
\end{tabular}

Sumber : Data Olahan 2015

Berdasarkan tabel indeks penerapan nilai-nilai Islami bahwa aspek yang mendapat nilai tertinggi yaitu "ketika waktu shalat telah tiba terdengar kumandang adzan sampai di ruang pasien dirawat" dengan nilai indeks sebesar 4,75. Sedangkan aspek yang mendapat nilai indek terendah yaitu "di kamar tempat pasien di rawat terhadap ketersediaan media untuk tayamum

Kualitas Pelayanan Masyarakat di Rumah Sakit Islam Ibnu Sina Kota Pekanbaru.

Berdasarkan hasil pengolahan data penerapan kualitas pelayanan masyarakat pada Rumah Sakit Islam Ibnu Sina Kota Pekanbaru tersebut, penulis dapat menjabarkan nilai perunsur, sebagai berikut :

dengan nilai indek sebesar 3,05

Tabel 3

Nilai terhadap Penerapan Kualitas Pelayanan

\begin{tabular}{|c|l|c|}
\hline No & \multicolumn{1}{|c|}{ Aspek } & $\begin{array}{c}\text { Nilai } \\
\text { (Persen) }\end{array}$ \\
\hline 1 & Komunikasi (Comunication) & 90,71 \\
\hline 2 & Kompetensi (Competence) & 88,89 \\
\hline 3 & Kesopanan (Courtessy) & 87,88 \\
\hline 4 & Responsivitas (Responsiveness) & 87,88 \\
\hline 5 & Pengertian (Understanding) & 86,87 \\
\hline 6 & Keamanan (Assurance) & 86,87 \\
\hline 7 & Kredibilitas (Credibility) & 84,44 \\
\hline 8 & Reliabilitas (Reliabelity) & 83,16 \\
\hline 9 & Tampilan fisik (Tangiblis) & 82,92 \\
\hline
\end{tabular}




\begin{tabular}{|c|c|c|}
\hline 10 & Akses (Acces) & 48,89 \\
\hline & Rata-rata & 82,85 \\
\hline
\end{tabular}

Berdasarkan tabel indeks kepuasan pelayanan di atas, bahwa aspek yang mendapat nilai tertinggi adalah "komunikasi (comunication)" dengan nilai sebesar 90,71\%. Sedangkan aspek yang mendapat nilai terendah adalah aspek "akses (access)" dengan nilai sebesar 48,89\%.

\section{Analisis Data Kuantitatif}

Dalam mengolah data kuantitatif penulis menggunakan program SPSS for Windows versi 16, menggunakan regresi linear sederhana. Dalam penelitian ini dapat dilihat hubungan antara variabel bebas (nilai-nilai keislaman) terhadap variabel terikat (Kualitas Layanan). Sebagai berikut:

\section{Uji Asumsi Kelasik}

Dalam analisis regresi ini perlu juga dianalisis masalah heteroskedastisitas, multikolinearitas dan otokorelasi.

1. Uji Normalitas

Melalui Uji Normalitas variabel dependent Kualitas Layanan serta variabel independent penerapan nilai-nilai keislaman memenuhi asumsi normalitas, karena data menyebar di sekitar garis diagonal dan mengikuti arah garis diagonal. Hal ini dapat dilihat pada gambar di bawah ini:

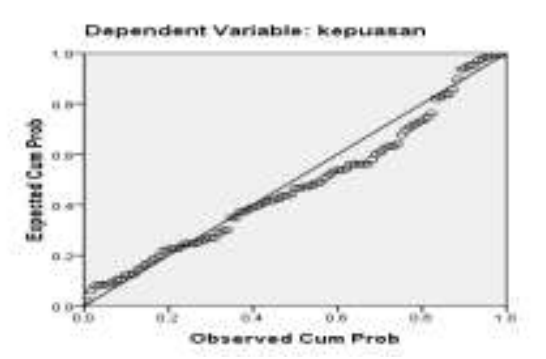

2. Uji Heteroskedastisitas

Heteroskedastisitas terjadi karena perubahan situasi yang tidak tergambarkan dalam spesifikasi model regresi sehingga terjadi perubahan tingkat keakuratan data. Masalah Heteroskedastisitas bisa dideteksi pada grafik scatter plot, jika tidak ada pola yang jelas, serta titik-titik menyebar di atas dan di bawah angka 0 pada sumbu $Y$, berarti model regresi yang digunakan bebas dari masalah heteroskedastisitas. Dari print out SPSS penelitian ini grafik scatter plot tidak membentuk pola tertentu, tetapi tersebar secara acak menyebar di atas dan di bawah angka 0 pada sumbu $Y$, berarti bebas dari masalah heteroskedastisitas.

3. Uji Multikolinearitas

Multikolinearitas adalah keadaan di mana variabel-variabel independen dalam persamaan regresi mempunyai korelasi (hubungan) yang erat satu dengan yang lainnya. Deteksi terhadap gangguan multikolinearitas adalah dari nilai VIF (Varian Inflation factor). Jika VIF> 0,1 berarti tidak terjadi multikolinearitas. Pada penelitian ini diperoleh VIF untuk variabel penerapan nilai-nilai keislaman 
bernilai 1. Nilai ini lebih besar dari

0,1 berarti penelitian ini bebas dari

masalah multikolinearitas.

Tabel 4 Coefficients ${ }^{a}$

\begin{tabular}{|r|r|r|r|}
\hline \multirow{2}{*}{ Model } & \multicolumn{2}{|c|}{ Correlations } & \multicolumn{1}{c|}{$\begin{array}{c}\text { Collinearity } \\
\text { Statistics }\end{array}$} \\
\cline { 2 - 4 } & \multicolumn{1}{|c|}{ Part } & Tolerance & \multicolumn{1}{c|}{ VIF } \\
\hline 1 (Constant) & & & \\
Keislaman & .458 & 1.000 & 1.000 \\
\hline
\end{tabular}

a. Dependent Variable: kepuasan

Sumber : Data Olahan 2015

4. Uji Autokorelasi

Untuk menguji apakah ada

masalah Autokorelasi dalam

persamaan regresi sederhana,

Tabel 5 Model Summary ${ }^{b}$

\begin{tabular}{|r|c|r|r|r|r|}
\hline Model & $\mathrm{R}$ & $\begin{array}{c}\mathrm{R} \\
\text { Square }\end{array}$ & $\begin{array}{c}\text { Adjuste } \\
\mathrm{d} \text { R } \\
\text { Square }\end{array}$ & $\begin{array}{c}\text { Std. Error } \\
\text { of the } \\
\text { Estimate }\end{array}$ & $\begin{array}{l}\text { Durbin- } \\
\text { Watson }\end{array}$ \\
\hline 1 & $.458 \mathrm{a}$ & .210 & .202 & 16.59636 & 1.437 \\
\hline
\end{tabular}

a. Predictors: (Constant), keislaman

b. Dependent Variable: kepuasan

Sumber : Data Olahan 2015

Masalah otokorelasi disebut juga korelasi serial, misalnya data pertama berkorelasi dengan data kedua, dan seterusnya. Ketentuan dalam menentukan masalah ini adalah melalui nilai Durbin Watson (DW):

a. Jika DW > batas atas (dU), maka tidak ada otokorelasi.

b. Jika DW < batas atas (dU), maka terjadi otokorelasi. dapat dilihat pada tabel di bawah 
PENGUJIAN HIPOTESIS

Dalam mengolah data kuantitatif penulis menggunakan program SPSS for Windows versi 16, menggunakan regresi linear sederhana. Dalam penelitian ini dapat dilihat hubungan antara variabel bebas (nilai-nilai keIslaman) terhadap variabel terikat (kualitas layanan). Adapun persamaan regresi linear sederhananya adalah :

$\mathrm{Y}=\mathrm{a}+\mathrm{bX}+\mathrm{e}$

Dimana :

$\mathrm{Y}=$ Kualitas pelayanan

$\mathrm{a}=$ Konstanta

$\mathrm{b}=$ Koefisien regresi

$X=$ Penerapan nilai-nilai keislaman

$\mathrm{e}=$ error

Tabel 6 Coefficients ${ }^{a}$

\begin{tabular}{|c|c|c|c|c|c|c|c|c|c|c|}
\hline \multirow{2}{*}{ Model } & \multicolumn{2}{|c|}{$\begin{array}{l}\text { Unstandardize } \\
\text { d Coefficients }\end{array}$} & \multirow{2}{*}{$\begin{array}{c}\text { Standa } \\
\text { rdized } \\
\text { Coeffic } \\
\text { ients }\end{array}$} & \multirow{2}{*}{$\mathrm{T}$} & \multirow{2}{*}{ Sig. } & \multicolumn{3}{|c|}{ Correlations } & \multicolumn{2}{|c|}{$\begin{array}{c}\text { Collinearity } \\
\text { Statistics }\end{array}$} \\
\hline & B & $\begin{array}{l}\text { Std. } \\
\text { Error }\end{array}$ & & & & $\begin{array}{c}- \\
\text { orde } \\
r\end{array}$ & $\begin{array}{c}\text { Part } \\
\text { ial }\end{array}$ & Part & $\begin{array}{l}\text { Toler } \\
\text { ance }\end{array}$ & VIF \\
\hline $\begin{array}{l}1 \text { (Consta } \\
\text { nt) }\end{array}$ & 103.586 & 19.950 & & 5.192 & .000 & & & & & \\
\hline $\begin{array}{l}\text { keislam } \\
\text { an }\end{array}$ & 1.248 & .246 & .458 & 5.079 & .000 & .458 & .458 & .458 & 1.000 & 1.000 \\
\hline
\end{tabular}

a. Dependent Variable:

kepuasan

Sumber: Data Olahan 2015

Dari hasil olahan SPSS di atas, maka dapat diperoleh hasil sebagai berikut:

$$
Y=103,586+1,248 X+e
$$

Dari persamaan tersebut dapat dijelaskan hal-hal sebagai berikut :

1. Jika $X=$ nol maka $Y=103,586$, artinya jika tidak ada penerapan nilai-nilai keislaman, maka kualitas pelayanan bernilai 1,248. Faktor lain dianggap konstan. Artinya jika tenaga medis baik perawat, dokter atau yang lainnya tidak melakukan aktivitas yang mencerminkan nilai-nilai keislaman dalam melakukan tindakan kepada pasien, pasien tetap merasakan kepuasan. Hal ini karena pelayanan rumah sakit ini berbeda dengan pelayanan yang lainnya, dalam kondisi yang darurat pasien mesti segera mendapat penanganan, meskipun penerapan nilai-nilai keislaman tidak dilakukan menurut pasien asalkan mereka segera ditangani mereka merasakan kualitas pelayanan yang baik. Meskipun 
tenaga medis dan para medis menerapkan nilai-nilai keislaman, tetapi pasien merasa lambat penanganannya, maka pasien tidak merasakan kualitas pelayanan yang baik.

2. Hubungan antara variabel penerapan nilai-nilai keislaman dan kualitas pelayanan bernilai positif, artinya jika penerapan nilai-nilai keislaman meningkat maka kualitas pelayanan akan meningkat dan sebaliknya. Setiap peningkatan 1 satuan variabel penerapan nilai-nilai keislaman akan meningkatkan 1,248 satuan kualitas pelayanan. Dari hasil kuesioner tentang penerapan nilai-nilai keislaman tersebut $81 \%$ (nilai rata-rata) responden menjawab "benar dan sangat benar kenyataannya", apabila ini meningkat maka akan meningkatkan kualitas pelayanan yang dirasakan oleh pasien. Seperti membaca basmalah pada saat akan melakukan suatu tindakan kepada pasien, jika pasien tahu tenaga medis di rumah sakit Ibnu Sina ini baik perawat, dokter atau yang lainnya membaca basmalah sebelum melakukan suatu tindakan terhadap dirinya, mereka merasa lebih tenteram. Dalam hal ini ada responden yang menjawab kurang benar/ tidak benar adanya $19 \%$, hal ini bisa saja ada tenaga medis yang membaca, tetapi dalam hati saja sehingga tidak terdengar oleh pasien dan pasien tidak tahu apakah tenaga medis tersebut berdoa atau tidak sebelum melakukan suatu tindakan. Meskipun pasien yang dilayani tidak beragama Islam, kewajiban berdoa sebelum berbuat sesuatu ini adalah berlaku sama.

\section{Uji Parsial (Uji t)}

Uji t digunakan untuk melihat pengaruh variabel bebas secara parsial terhadap variabel terikat. Uji $\mathrm{t}$ juga untuk menguji signifikansi konstanta dari setiap variabel independent. Apabila $\mathrm{t}$ hitung $>\mathrm{t}$ tabel maka Ho ditolak dan $\mathrm{Ha}$ diterima dan sebaliknya.

Hipotesis yang digunakan:

Ho $=$ Variabel bebas (penerapan nilai-nilai keislaman) tidak berpengaruh signifikan terhadap variabel terikat (kualitas pelayanan)

$\mathrm{Ha}=$ Variabel bebas (penerapan nilai-nilai keislaman) berpengaruh signifikan terhadap variabel terikat (kepuasan)

Dari hasil olah data SPSS tersebut, maka diperoleh $\mathrm{t}$ hitung :

1. Variabel Penerapan Nilai-nilai KeIslaman diperoleh $\mathrm{t}$ hitung sebesar 2,698, jika dibandingkan dengan $\mathrm{t}$ tabel pada $a=0,10$ dan degree of freedom $(\mathrm{df})=(\mathrm{n}-\mathrm{k}=99-1=98)$ yaitu 1,289, berarti $\mathrm{t}$ hitung $>\mathrm{t}$ tabel maka pengaruh variabel kemampuan signifikan terhadap variabel kualitas pelayanan.

2. Untuk variabel norma-norma diperoleh $\mathrm{t}$ hitung sebesar 1,422, jika dibandingkan dengan $t$ tabel pada $a=0,05$ dan degree of freedom $(\mathrm{df})=(\mathrm{n}-\mathrm{k}=100-2=98)$ yaitu 1,658 , berarti $t$ hitung $>t$ tabel maka pengaruh variabel 
kemampuan signifikan terhadap variabel kualitas pelayanan.

\section{Analisis Varian (Uji F)}

Analisis ini bertujuan untuk menunjukkan sumber-sumber variasi yang menjadi komponen dari variasi total model regresi. Dapat dilihat bagaimana pengaruh variabel bebas terhadap variabel terikat. Hipotesisnya :

Ho : $\mathrm{B}=0$

Ha : $\mathrm{B} \neq 0$

$F$ hitung dibandingkan dengan $\mathrm{F}$ tabel, jika $\mathrm{F}$ hitung $>\mathrm{F}$ tabel, Ho ditolak, Ha diterima. Dalam penelitian ini diperoleh hasil $F$ hitung 25,795. F tabel pada $\alpha=0,05$ adalah 3,92. Maka F hitung > F tabel, Ho ditolak dan Ha diterima. Artinya Penerapan Nilai-nilai Keislaman secara sangat signifikan mempengaruhi kualitas pelayanan.

\section{Koefisien Korelasi dan Determinasi}

Koefisien korelasi (R) menunjukkan kuat atau tidaknya hubungan antara variabel $\mathrm{X}$ (variabel bebas) dan $Y$ (variabel terikat). Dalam penelitian ini bernilai 0,458 , artinya keeratan hubungan variabel bebas (Penerapan Nilai-nilai KeIslaman) terhadap kualitas pelayanan rendah, menurut Firdaus (2011: 33) nilai koefisien korelasi antara 0,3 sampai 0,4 menunjukkan adanya korelasi yang rendah.

Koefisien determinasi adalah koefisien yang menunjukkan persentase pengaruh variabel bebas terhadap variabel terikat. Dari hasil print out SPSS diperoleh sebesar $\mathrm{R}^{2}=$ 0,210, artinya variabel Penerapan Nilai-nilai Keislaman menentukan variabel kualitas pelayanan sebesar 0,21 atau $21 \%$, sisanya $79 \%$ ditentukan oleh variabel lain yang tidak masuk dalam penelitian ini. Dari teori Kualitas Pelayanan faktor lain yang bisa mempengaruhi kualitas pelayanan adalah faktor exterior/ interior, kenyamanan dan keamanan ruangan, kelengkapan alat medis, jumlah petugas, ketanggapan petugas, kehandalan petugas, jumlah kelayakan pasien dalam satu ruangan, dan lain sebagainya. Dan bisa jadi faktor ini lebih menentukan kualitas pelayanan selain Penerapan Nilainilai Keislaman.

\section{PENUTUP}

\section{Kesimpulan}

Setelah penulis melakukan pengolahan data dan mendapatkan hasil penelitian ini, maka penulis dapat menyimpulkan manajemen pelayanan sebagai berikut :

1. Pada Rumah Sakit Islam Ibnu Sina Kota Pekanbaru telah melakukan penerapan nilai-nilai keislaman tersebut secara keseluruhan dapat dikatakan implementasinya "baik".

2. Penerapan kualitas pelayanan masyarakat yang dilakukan oleh Rumah Sakit Islam Ibnu Sina Kota Pekanbaru secara keseluruhan juga tergolong "baik".

3. Penerapan Nilai-nilai Keislaman dan Kualitas Pelayanan Masyarakat pada Rumah Sakit. Islam Ibnu Sina Kota Pekanbaru jika dihubungkan dengan menggunakan metode kuantitatif 
terjadi hubungan yang positif, yaitu 0,458. Hal ini berarti semakin tinggi (baik) penerapan nilai-nilai Islam, maka akan semakin tinggi (baik) pula kualitas pelayanannya.

\section{Saran}

Implikasi praktis yang dalam penelitian ini adalah saran kepada para manajer rumah sakit. adapun saran yang bisa diberikan adalah bahwa penerapan nilai-nilai Islam itu sebaiknya terus ditingkatkan agar kualitas pelayanan masyarakat rumah sakit itu juga semakin meningkat. Saran kepada para peneliti selanjutnya adalah bahwa mereka sebaiknya menindaklanjuti hasil penelitian ini, khususnya untuk menjelaskan lebih mendalam mengapa dalam rumah sakit yang berkonsep Islami ini justru bukubuku keagamaan, khususnya alquran serta alat shalat, kurang tersedia di dalam ruangan pasien dan juga media yang digunakan untuk bertayamum ketika pasien tidak dapat menggunakan air untuk berwuduk. Di samping itu, mereka juga sebaiknya meneliti lebih lanjut untuk menjelaskan mengapa rumah sakit ini memiliki akses yang relatif sedikit untuk kemasyarakatan.

\section{DAFTAR KEPUSTAKAAN}

Denhart\&Denhart, 2003. Balancing Customer Perceptions and Expectation, New York, the Free Press., Penerjemah Pasaribu, 2013. Pelayanan Publik Baru Dari Manajemen Steering Ke Serving,
Penerjemah Pasaribu, 2013,

Kreasi Wacana, Yogyakarta.

Guwandi, 1991. Pelayanan Kesehatan

Rumah Sakit. Rineka Cipta. Jakarta.

Hasniati, 2008. Sikap Dan Prilaku Birokrat Garis-Depan Dalam Pelayanan Publik Ditinjau Dari Perspektif Syariat Islam. Artikel Al-Fikr Volume 17 Nomor 1 Tahun 2013.

Kebudayaan Dan Politik, Volume 20, Nomor 1:23-34.

Laksono Trisantoro, Good Governance dan Sistem Menjaga Mutu Pelayanan Kesehatan, Surabaya, 2005.

Permendagri No. 6 Tahun 2007 tentang Petunjuk Teknis Penyusunan dan Penetapan Standar Pelayanan Minimal.

Pasolong, Harbani, 2011. Teori Administrasi Publik. Alfabeta, Bandung.

Pramuka, Gatot: Masalah Birokrasi Sebagai Pelayan Publik, Jurnal Masyarakat

Pribadi, Ulung, 2012. Nilai-Nilai Agama dan Pelayanan Publik Studi Kasus di RS Muhammadiyah Yogyakarta. Penelitian Strategis Universitas Muhammadiyah Yogyakarta.

Syafri, Wirman, 2012. Studi Tentang Administrasi Publik. Erlangga, Jakarta.

Sugiyono, 2010. Meteode Penelitian Administrasi. Alfabeta, Bandung. 2013. Metode Penelitian Kuantitatif, Kualitatifdan RED. Alfabeta, Bandung.

Singarimbun,Sofian, 1989. Metode Penelitian Survey. LP3S, Jakarta. 
Zeithaml, V.A., Parasuraman \& L.L. Berry, Delivering Quality Services:

Ketentuan Peraturan Perundangundangan :

Undang-Undang No. 25 Tahun 2009 tentang Pelayanan Publik.

Peraturan Pemerintah No. 65 Tahun 2005 tentang
Pedoman Penyusunan dan Penerapan Standar Pelayanan Minimal

Kepmenpan

63/KEP/M.PAN/7/2003

tentang Pedoman Penyelenggaraan Pelayanan.

Kepmenpan No.

KEP/25/M.PAN/2/2004 tentang Pedoman Umum Penyusunan Indeks Kepuasan 